\title{
Proceeding
}

Supplementary Issue: Autumn Conferences of Sports Science. Costa Blanca Sports Science Events, 18-19 December 2020. Alicante, Spain.

\section{Body composition analysis in adolescent male athletes: Skinfold versus ultrasound}

\author{
ALESSANDRO LICCARDO $\triangleleft$, DOMENICO TAFURI, ANTONIO CORVINO \\ Department of Motor Sciences and Wellness, University of Naples "Parthenope", Naples, Italy
}

\begin{abstract}
Introduction: Aim of this study was to compare the repeatability of the evaluation of body composition with the skinfold measuring technique and the portable ultrasound measuring technique BodyMetrix TM BX2000, in order to estimate body fat percentage in adolescents athletes. Materials e Methods: Twenty adolescent male athletes have been recruited in a basketball centre. Skinfold and ultrasound measurements were detected on the right side of the body in 2 anatomical points: triceps and subscapular. Results: The results obtained by both techniques showed a high correlation with final body fat mass (\%), although differences have been observed with both methods in each anatomical site. Conclusions: The assessment of body composition is an important parameter that allows us to have an estimate of the percentage of body fat. Therefore, it is a fundamental criterion for both the professionals of wellness and the athlete, since allows to verify the results produced by dietary plans and training.
\end{abstract}

Keywords: Body composition; Portable ultrasound; Skinfold thickness; Sport; Imaging.

\section{Cite this article as:}

Liccardo, A., Tafuri, D., \& Corvino, A. (2021). Body composition analysis in adolescent male athletes:

Skinfold versus ultrasound. Journal of Human Sport and Exercise, 16(2proc), S239-S244. doi:https://doi.org/10.14198//hse.2021.16.Proc2.08

Corresponding author. Department of Motor Sciences and Wellness, University of Naples "Parthenope", Naples, Italy.

E-mail: alessandro.liccardo@uniparthenope.it

Abstract submitted to: Autumn Conferences of Sports Science. Costa Blanca Sports Science Events, 18-19 December 2020. Alicante, Spain.

JOURNAL OF HUMAN SPORT \& EXERCISE ISSN 1988-5202

(c) Faculty of Education. University of Alicante

doi:10.14198/jhse.2021.16.Proc2.08 


\section{INTRODUCTION}

Body composition analysis is the evaluation and quantification of various compartments that constitute the human body. The study of body composition has played over time a significant role in both clinical and sport context, representing a major area of research thanks to the information that it can provide for the estimation of energy requirements and nutritional status (Hendler RG et al., 1995; Mazzeo et al, 2016). The assessment of body composition is also of extreme importance in both sedentary subject for a close relationship with the health, and in the athlete in order to assess changes resulting from the practice of sport (Nindl BC et al., 1996; Monda et al, 2009; Beechy L et al., 2012; Raiola \& Tafuri, 2015; Raiola, Tafuri \& Altavilla, 2015).

Body composition evaluation techniques can be divided into direct and indirect methods. The only direct method is the evaluation of the body by fat esterification. Some of the indirect methods for evaluating body composition are: plicometry (Duren DL et al., 2008), waist and abdominal circumference measurement, sagittal and transverse diameter measurement, densitometry (DXA) (Duren DL et al., 2008; Webber J et al., 1994), computed tomography (CT) (Sandomenico $F$ et al., 2019; Corvino A et al., 2020), magnetic resonance (MR) (Ross R et al., 2000; Corvino A et al., 2020), impedance measurement (BIA) (Böhm A et al., 2013), air plethysmography "BOD POD" (Wagner DR et al., 2000; Fields DA et al., 2002), hydrostatic weighing, and ultrasound (US) (Catalano $O$ et al. 2019; Sandomenico et al., 2020; Corvino A et. al., 2020).

Recently, US technology has been revalued for body composition assessment, especially in the B-mode technique. US thickness measurement in adipose, muscle and other tissues result in higher accuracies when compared with skinfolds. However, appropriate protocols for estimates based on US have not yet been standardized (Wagner DR, 2013).

Also, contrast-enhanced ultrasound (CEUS) is a "new" simple, immediate, and effective US tool: microbubbles circulate freely inside the body and constitute an intravascular contrast agent (Corvino A et al., 2017). Recently, it has been recognized that CEUS permit analysis of both macro- and microvascularity in order to assess changes resulting from sport activity (Mitchell WK et al., 2013; Garzillo et al, 2017; Suo S et al., 2018). Similarly, skeletal muscle perfusion in response to exercise have also been studied with MR and CT angiography compared with conventional digital subtraction angiography by some authors (Cangiano $\mathrm{G}$ at al., 2019). However, future studies are needed.

\section{MATERIALS AND METHODS}

Twenty young men basketball player who practiced training with overloads at least for a year three times a week were recruited at a basketball centre; them and their parents provided informed consent to participate in the study. The materials used to collect the data were: SECA 711 scale with altimeter Seca 220, plicometer Accu Measure Fitness 3000, portable ultrasound BodyMetrix (BX-2000 IntelaMetrix, Inc.), a laptop. For each athlete the examination of skinfold and of portable ultrasound were performed separately and cyclically twice by the same operator. This means that for a same anatomical point the measurement was performed twice with both techniques of the study. The acquisition of skinfold data was realized as a standardized procedure according to Slaughter MH (Slaughter MH et al., 1988).

\section{RESULTS}

Twenty young men basketball player, average age of $14.95 \pm 0.69$, height of $161 \pm 0.08 \mathrm{~cm}$, weight of 59.75 $\pm 7.78 \mathrm{~kg}$, BMl of $23.05 \pm 1.75 \mathrm{~kg} / \mathrm{m}^{2}$. 
The variables examined were: the individual skinfold measurement relating to specific anatomic points, the adipose tissue thickness detected by US and the relative percentages of fat mass obtained with both techniques. All statistical data were analysed using SPSS software (IBM, Inc., Armonk, NY): statistical significance was accepted for $p<.05$. For all variables has been calculated the average and the standard deviation, and the distribution of normality was verified by Shapiro-Wilk test. The differences have been evaluated with the t-test: $p<.001$, while the correlation of the values obtained through the skinfold measurement and those obtained through fat body measurement by portable US, for the average of each measurement and each anatomical site, was assessed by the correlation of Pearson highlighting a value close to 1 so as to show that the two examined techniques are strictly comparable and reproducible (Table 1a-d).

(a)

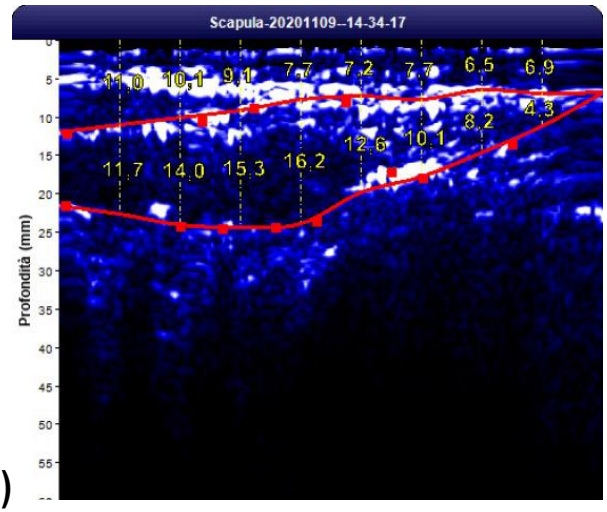

(b)

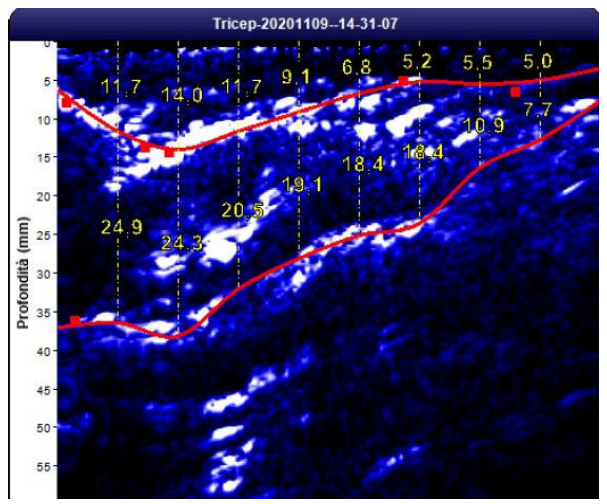

Figure 1. (a) BodyMetrix US image of subscapular. The top line indicates the subcutaneous fat-muscle interface. The bottom line indicates the muscle-bone boundary. (b) BodyMetrix US image of triceps.

Our data confirm the reliability of the US method in the study of the subcutaneous adipose tissue, demonstrating the importance of contextualization of body composition in the athletes.

Table 1a. Mean \pm SD $(\mathrm{mm})$ of skin thickness by SF.

\begin{tabular}{lcc}
\hline & Skinfold triceps & Skinfold subscapular \\
\hline I measurement & $9.31 \pm 3.90$ & $9.68 \pm 4.59$ \\
II measurement & $9.31 \pm 4.06$ & $9.59 \pm 4.53$ \\
\hline
\end{tabular}

Table $1 \mathrm{~b}$. Mean $\pm \mathrm{SD}(\mathrm{mm})$ of skin thickness by US.

\begin{tabular}{lcc}
\hline & US triceps & US subscapular \\
\hline I measurement & $3.72 \pm 1.05$ & $3.95 \pm 1.02$ \\
II measurement & $3.65 \pm 0.99$ & $3.93 \pm 1.05$ \\
\hline
\end{tabular}

Table 1c. The body fat mass percentage (mean \pm SD) by SF and US.

\begin{tabular}{lcc}
\hline & Skinfold (\%) & US (\%) \\
\hline I measurement & $16.57 \pm 5.95$ & $13.39 \pm 3.33$ \\
II measurement & $16.50 \pm 5.96$ & $13.32 \pm 3.19$ \\
\hline
\end{tabular}

Table 1d. Correlation between SF and US of three anatomic points.

\begin{tabular}{lcc}
\hline & Triceps & Subscapular \\
\hline Correlation coefficient & .793 & .800 \\
\hline
\end{tabular}




\section{DISCUSSION AND CONCLUSIONS}

Despite the five decades passed since the first publication on the use of US for the measurement of adipose tissue (Bullen BA et al., 1965), this evaluation technique is not yet frequently used by various professionals interested in the study of body composition. The portable ultrasound BodyMetrix ${ }^{\mathrm{TM}}$ BX2000, which we used in our study, has several advantages over other imaging devices and laboratory analysis techniques of body composition such as: the absence of ionizing radiation, the size and the portability of the device and the relatively affordable cost compared to other laboratory methods. For this reason, it can also be compared to methods such as skinfold thickness measurement.

However, even if Toomey (Toomey $C$ et al., 2011) provided some recommendations on the use of US in order to measure subcutaneous adipose tissue, there is not still a standardization concerning the different aspects of measurement (for example, the optimal scanning frequency and the scanning distance or length, etc.). Thus, the reliability of the interpretation of the results depends on operator skills. In our case, however, the supplied software designed specifically for the analysis of body composition helped us to reduce to a minimum these limitations. Probably this is the reason why the final percentage of body fat calculated with two different techniques does not show significant differences, although differences have been observed with both methods in the measurement of each anatomical site. Thus, a possible starting point for a future research could be an implementation of the study with an additional method for the analysis of body composition considered as a gold standard method as DXA.

\section{REFERENCES}

Beechy L, Galpern J, Petrone A, Das SK. Assessment tools in obesity - psychological measures, diet, activity, and body composition. Physiol Behav, 2012; 107(1):154-71. https://doi.org/10.1016/j.physbeh.2012.04.013

Böhm A, Heitmann BL. The use of bioelectrical impedance analysis for body composition in epidemiological studies. Eur J Clin Nutr, 2013; 67 Suppl 1:S79-85. https://doi.org/10.1038/ejcn.2012.168

Bullen BA, Quaade F, Olessen E, Lund SA. Ultrasonic reflections used for measuring subcutaneous fat in humans. Hum Biol, 1965; 37(4):375-84.

Cangiano G, Corvino F, Giurazza F, Silvestre M, Amodio F, Corvino A, Niola R. Endovascular Treatment of Simultaneous lliac and Superficial Femoral Arterial Pseudoaneurysms After Stenting Procedure $\begin{array}{llll}\text { Complications. } \quad \text { Vasc } \quad \text { Endovascular } & \text { Surg, }\end{array}$ https://doi.org/10.1177/1538574418805588

Catalano O, Alfageme FR, Varelli C, Bard R, Corvino A, Wortsman X. Skin cancer. Findings and role of high-resolution ultrasound. J Ultrasound, 2019; 22(4): 423-431. https://doi.org/10.1007/s40477-019$\underline{00379-0}$

Corvino A, Catalano O, Corvino F, Sandomenico F, Petrillo A. Diagnostic Performance and Confidence of Contrast-Enhanced Ultrasound in the Differential Diagnosis of Cystic and Cysticlike Liver Lesions. AJR Am J Roentgenol, 2017; 209(3):W119-W127. https://doi.org/10.2214/AJR.16.17062

Corvino A, Catalano O, de Magistris G, Corvino F, Giurazza F, Raffaella N, Vallone G. Usefulness of doppler techniques in the diagnosis of peripheral iatrogenic pseudoaneurysms secondary to minimally invasive interventional and surgical procedures: imaging findings and diagnostic performance study. J Ultrasound, 2020; 23(4):563-573. https://doi.org/10.1007/s40477-020-00475$\underline{6}$ 
Corvino A, Setola SV, Sandomenico F, Corvino F, Catalano O. Synchronous tumours detected during cancer patient staging: prevalence and patterns of occurrence in multidetector computed tomography Pol J Radiol, 2020; 85:e261-e270. https://doi.org/10.5114/pir.2020.95781

Corvino A, Catelli A, Trovato $P$, Pane F, Corvino $F$. Volar ganglion cyst of the wrist simulating a radial artery pseudoaneurysm: A case report. EuroMed BioMed J, 2020; 15:90-93.

Duren DL, Sherwood RJ, Czerwinski SA, Lee M, Choh AC, Siervogel RM, Cameron Chumlea W. Body composition methods: comparisons and interpretation. J Diabetes Sci Technol, 2008; 2(6):1139-46. https://doi.org/10.1177/193229680800200623

Fields DA, Goran MI, McCrory MA. Body-composition assessment via air-displacement plethysmography in adults and children: a review. Am J Clin Nutr, 2002; 75(3):453-67. https://doi.org/10.1093/ajcn/75.3.453

Garzillo, C., Pugliese, M., Loffredo, F., \& Quarto, M. (2017). Indoor radon exposure and lung cancer risk: a meta-analysis of case-control studies. Transl Cancer Res, 6(Suppl 5), S934-S943. https://doi.org/10.21037/tcr.2017.05.42

Hendler RG, Welle SL, Statt MC, Barnard R, Amatruda JM. The effects of weight reduction to ideal body weight on body fat distribution. Metabolism, 1995; 44(11):1413-1416. https://doi.org/10.1016/00260495(95)90139-6

Mazzeo, F., Santamaria, S., Monda, V., (...), Messina, G., Monda, M. (2016). Dietary supplements use in competitive and non-competitive boxer: An exploratory study. Biology and Medicine, $8(4), 1000294$.

Mitchell WK, Phillips BE, Williams JP, Rankin D, Smith K, Lund JN, Atherton PJ. Development of a new Sonovue ${ }^{\mathrm{TM}}$ contrast-enhanced ultrasound approach reveals temporal and age-related features of muscle microvascular responses to feeding. Physiol Rep, 2013; 1(5):e00119. https://doi.org/10.1002/phy2.119

Monda, M., Viggiano, An., Vicidomini, C., (...), Tafuri, D., De Luca, B. (2009). Expresso coffee increases parasympathetic activity in young, healthy people. Nutritional Neuroscience, 12(1), pp. 43-48. https://doi.org/10.1179/147683009X388841

Nindl BC, Friedl KE, Marchitelli LJ, Shippee RL, Thomas CD, Patton JF. Regional fat placement in physically fit males and changes with weight loss. Medicine and science in sports and exercise, 1996; 28(7): 786-793. https://doi.org/10.1097/00005768-199607000-00003

Raiola, G., Tafuri, D., Altavilla, G. (2015). Physical activity and its relation to body and ludic expression in childhood. Mediterranean Journal of Social Sciences, 6(3), pp. 293-296.

Raiola, G., Tafuri, D. (2015).Teaching method of physical education and sports by prescriptive or heuristic learning. Journal of Human Sport and Exercise, 10(Specialissue), pp. S377-S384. https://doi.org/10.14198/jhse.2015.10.Proc1.28

Ross R, Goodpaster B, Kelley D, Boada F. Magnetic resonance imaging in human body composition research. From quantitative to qualitative tissue measurement. Ann N Y Acad Sci, 2000; 904:12-7. https://doi.org/10.1111/i.1749-6632.2000.tb06415.x

Sandomenico F, Corvino A, Ronza FM, Catalano O, Fazioli F, De Chiara A, Campanino MR, Porcaro M, Tafuri D, Petrillo A. Recurrence of tumoral calcinosis: a case report. Acta Biomed, 2019; 90(4):587594. https://doi.org/10.23750/abm.v90i4.8251

Sandomenico F, Corvino A, Setola SV, Simonetti I, Porcaro M, Trovato P, Catalano O, Petrillo A. Postamputation neuroma of radial nerve in a patient with ephitelioid sarcoma: case report and literature review. Acta Bio Med, 2020. 91(1):122-127. https://doi.org/10.23750/abm.v91i1.8510

Slaughter MH, Lohman TG, Boileau RA, et al. Skinfold equations for estimation of body fatness in children and youth. Hum Biol, 1988; 60:709-23. 
Suo S, Zhang L, Tang H, Ni Q, Li S, Mao H, Liu X, He S, Qu J, Lu Q, Xu J. Evaluation of skeletal muscle microvascular perfusion of lower extremities by cardiovascular magnetic resonance arterial spin labeling, blood oxygenation level-dependent, and intravoxel incoherent motion techniques. J Cardiovasc Magn Reson, 2018; 20(1):18. https://doi.org/10.1186/s12968-018-0441-3

Toomey C, McCreesh K, Leahy S, Jakeman P. Technical considerations for accurate measurement of subcutaneous adipose tissue thickness using B-mode ultrasound. Ultrasound, 2011; 19(2), 91-96. https://doi.org/10.1258/ult.2011.010057

Wagner DR. Ultrasound as a tool to assess body fat. J Obes, 2013; 2013:280713. https://doi.org/10.1155/2013/280713

Wagner DR, Heyward VH, Gibson AL. Validation of air displacement plethysmography for assessing body composition. Med Sci Sports Exerc, 2000; 32(7):1339-44. https://doi.org/10.1097/00005768$\underline{200007000-00023}$

Webber J, Donaldson M, Allison SP, Macdonald IA. A comparison of skinfold thickness, body mass index, bioelectrical impedance analysis and dual-energy X-ray absorptiometry in assessing body composition in obese subjects before and after weight loss. Clin Nutr, 1994; 13(3):177-82. https://doi.org/10.1016/0261-5614(94)90098-1

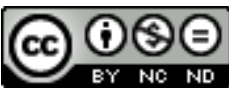

This work is licensed under a Attribution-NonCommercial-NoDerivatives 4.0 International (CC BY-NC-ND 4.0). 